\title{
Променевий клапоть передпліччя в реконструктивній хірургії голови та шиї. Досвід застосування та вибір венозної системи тканинного клаптя
}

\author{
Національний інститут раку, Київ \\ Одержано: 1.09.2021 \\ Прийнято до друку: 14.09.2021 \\ DOI: $10.32471 /$ clinicaloncology.2663-466X.41-1.27900
}

\begin{abstract}
Вступ. Методики забору променевого клаптя передпліччя (ПКП) постійно удосконалюються та спрямовані на зниження частоти післяопераційних ускладнень, покращення приживання тканинного клаптя та функціональних результатів реконструкції. Мета. Вивчити функціональні результати застосування ПКП для заміщення дефектів язика і щоки та порівняти ефективність венозних систем тканинного клаптя. Матеріали та методи. Проведено ретроспективний аналіз результатів реконструктивновідновного лікування 75 хворих на місцево-поширений плоскоклітинний рак язика та слизової оболонки щоки, яким для пластичного заміщення операційних дефектів застосовано ПКП у Національному інституті раку в період 2009-2020 рр. Результати. Показники функціонального статусу за шкалою функціонування для хворих на рак голови та шиї (Performance Status Scale for Head and Neck Cancer Patients - PSS-HN) при заміщенні половинних дефектів язика, субтотальних дефектів язика та дефектів щоки: повноцінність дієти $-83,7 \pm 9,3 ; 61,0 \pm 9,4 ; 85,7 \pm 13,4$ балів відповідно; харчування на людях $-80,8 \pm 14,2$; $64,5 \pm 12,5 ; 80,6 \pm 14,5$ балів відповідно; зрозумілість мови $-87,5 \pm 12,7 ; 66,1 \pm 12,2 ; 92,9 \pm 11,6$ балів відповідно. У групі хворих, яким один венозний анастомоз накладали з глибокою венозною системою ПКП, тромбоз мікросудинного анастомозу розвинувся у $3(6,4 \%)$ випадках, а у групі, у якій венозний анастомоз накладали з поверхневою венозною системою - у 2 (8,3\%) $($ p>0,05). Висновки. Застосування ПКП є ефективною методикою пластичного заміщення операційних дефектів язика і щоки, що дозволяє досягнути високих показників приживання тканинного клаптя та функціональної реабілітації онкологічних хворих. Не встановлено відмінностей у частоті венозного тромбозу при застосуванні ПКП з поверхневою та глибокою венозними системами.
\end{abstract}

Ключові слова: променевий клапоть передпліччя; дефект; функціональний статус; венозна система.

\section{ВСТУП}

Променевий клапоть передпліччя (ПКП) вперше був описаний та застосований G. Yang у 1981 р. [1]. Дотепер ПКП залишається методом вибору для пластичного заміщення багатьох дефектів голови та шиї у онкологічних хворих. Так, він може бути використаний при реконструкції органів та тканин ротової порожнини, ротоглотки, гортаноглотки та пластичного усунення окремих дефектів основи черепа і м'яких тканин голови та шиї [2-8]. Крім того, ПКП може бути виділений як кістково-шкірний клапоть для заміщення невеликих кісткових дефектів нижньої та верхньої щелеп [9].

До переваг ПКП слід віднести: легке виділення тканинного клаптя, надійність, постійність ангіоархітектоніки, достатньо довгу судинну «ніжку», тонку і пластичну тканину клаптя, можливість одночасної роботи двох бригад хірургів. Основним недоліком ПКП є естетичні порушення в донорській ділянці $[10,11]$.

Натепер успішність застосування ПКП наближається до 95\%, а основною причиною втрати тканинного клаптя $€$ венозна недостатність [12]. ПКП має дві основні венозні системи: поверхневу - включає головну вену та глибоку включає комітантні вени променевої артерії. У літературі немає консенсусу шодо того, яка венозна система є більш оптимальною для накладання анастомозу при перенесенні ПКП. Деякі автори надають перевагу поверхневій венозній системі, яка дозволяє накласти більш простий мікросудинний анастомоз. Інші автори вважають оптимальнішою глибоку венозну систему, стверджуючи, що вона забезпечує кращий венозний відтік 3 тканинного клаптя [13]. Нещодавно проведений метааналіз показав, що незважаючи на те що глибока венозна система забезпечила нижчий ризик венозної недостатності, даних метааналізу було недостатньо, щоб визначити, який тип венозної системи є більш оптимальним у разі накладання одного венозного анастомозу при пересадці ПКП [14].
Також було запропоновано забір ПКП з подвійним венозним дренажем за рахунок виділення антекубітальної перфорантної вени, яка з'єднує поверхневу та глибоку венозні системи. Виділення та включення в судинну «ніжку» антекубітальної перфорантної вени дозволяє дренувати ПКП з обох венозних систем через єдиний анастомоз з головною або серединнокубітальною веною. Спостерігається відновлення інтересу до цієї методики у дослідженнях останніх років $[12,15]$.

Метою даного дослідження було вивчення функціональних результатів застосування ПКП для замішення дефектів язика і щоки та порівняння ефективності венозних систем тканинного клаптя.

\section{МАТЕРІАЛИ I МЕТОДИ ДОСЛІДЖЕННЯ}

Проведено ретроспективний аналіз результатів реконструктивно-відновного лікування 75 хворих на місцево-поширений плоскоклітинний рак язика та слизової оболонки щоки, яким для пластичного заміщення операційних дефектів застосовано ПКП у Національному інституті раку за період з 2009-2020 pp.

Пластичне заміщення половинних дефектів язика. Реконструкцію язика ПКП після половинної резекції виконано у 30 хворих. Чоловіків було 27 (90\%), жінок - 3 (10\%). Середній вік пацієнтів становив $(55,9 \pm 9,3)$ років. Стадію III діагностовано у 21 (70 \%) хворого, стадію IV - у 9 (30\%). За критерієм Т розподіл був наступним: Т2 встановлено у 6 (20\%) хворих, T3 - у 24 (80 \%). Розподіл за критерієм N: N0 діагностовано у $10(33,3 \%), \mathrm{N} 1-$ у $11(36,7 \%), \mathrm{N} 2-$ у $9(30 \%)$ хворих.

Надомогіоїдну шийну дисекцію виконано у $10(33,3 \%)$, радикальну модифіковану шийну дисекцію - у 20 (66,7 \%) хворих. Шийну лімфодисекцію на стороні первинної пухлини проведено у $13(43,4 \%)$ пацієнтів, білатеральну - у 17 (56,6\%). Крайову резекцію нижньої щелепи виконано у $5(16,7 \%)$ хворих. Ад'ювантну променеву терапію (ПТ) отримали 21 (70 \%), хіміопроменеву терапію (ХПТ) - 9 (30\%) пацієнтів. 
Пластичне заміщення субтотальних дефектів язика. Реконструкцію язика ПКП після субтотальної резекції виконано у 31 хворого. Чоловіків було 27 (87,1 \%), жінок - 4 (12,9\%). Середній вік пацієнтів становив $(55,1 \pm 9,4)$ років. Стадію III діагностовано у 12 (38,7 \%) хворих, стадію IV - у 19 (61,3\%). За критерієм Т розподіл був наступним: Т3 встановлено у $21(67,7 \%)$ хворих, Т4 - у $10(32,3 \%)$ випадках. Розподіл за критерієм N: N0 діагностовано у 7 (22,6 \%), N1 у $10(32,3 \%), \mathrm{N} 2-$ у $14(45,2 \%)$ пацієнтів.

Надомогіоїдну шийну дисекцію виконано у $6(19,4 \%)$ хворих, радикальну модифіковану шийну дисекцію - у $23(74,2 \%)$, радикальну шийну дисекцію - у 2 (6,4\%) випадках. Шийну лімфодисекцію на стороні первинної пухлини проведено у 5 (16,1\%) пацієнтів, білатеральну - у 26 (83,9\%). Крайову резекцію нижньої щелепи виконано у 9 (29,0 \%) хворих. Ад'ювантну ПТ отримали $20(64,5 \%)$ пацієнтів, ХПТ - 11 (35,5\%).

Пластичне заміщення дефектів щоки. Пластичне заміщення дефектів щоки ПКП виконано у 14 пацієнтів. Чоловіків було $12(85,7 \%)$, жінок - 2(14,3\%). Середній вік пацієнтів становив $(59,9 \pm 7,9)$ років.

Усі дефекти після видалення первинної пухлини слизової оболонки щоки були більшими 4,5 см у найбільшому вимірі.

Плоскоклітинний рак слизової оболонки ретромолярної ділянки встановлено у 4 (28,6 \%), слизової оболонки щоки у $10(71,4 \%)$ хворих. Стадію III діагностовано у $10(71,4 \%)$ хворих, стадію IV - у 4 (28,6\%). За критерієм Т розподіл був наступним: Т2 встановлено у 2 (14,3\%) пацієнтів, Т3 - у $9(64,3 \%)$, T4 - у 3 (21,4 \%). Розподіл за критерієм N: N0 діагностовано у $7(50,0 \%)$ хворих, N1 - у $6(42,9 \%)$, N2 - в $1(7,1 \%)$.

Надомогіоїдну шийну дисекцію виконано у $8(57,1 \%)$ хворих, радикальну модифіковану шийну дисекцію - у 6 (42,9 \%). Шийну лімфодисекцію на стороні первинної пухлини проведено в $11(78,6 \%)$ пацієнтів, білатеральну - у $3(21,4 \%)$ випадках. Крайову резекцію нижньої щелепи виконано у 13 (92,8 \%) хворих.

Ад’ювантну ПТ отримали 12 (85,7 \%) пацієнтів, ХПТ $2(14,3 \%)$ хворих.

Вивчали післяопераційні ускладнення та функціональний статус хворих. Оцінка функції проводилася за шкалою функціонування для хворих на рак голови та шиї (Performance Status Scale for Head and Neck Cancer Patients - PSS-HN) через 6 міс після хірургічного лікування.

\section{РЕЗУЛЬТАТИ ТА ЇХ ОБГОВОРЕННЯ}

Пластичне заміщення половинних дефектів язика. Аналіз ускладнень після пересадки ПКП показав такі результати: у 1 (3,3\%) хворого розвинувся повний некроз клаптя, пов'язаний з венозним тромбозом мікросудинного анастомозу. У цього пацієнта виконано повторне реконструктивне втручання із застосуванням шкірно-фасціального клаптя надключичної артерії. Часткового та крайового некрозу тканинних клаптів у пацієнтів цієї групи не спостерігали. Отже, частота розвитку некрозу ПКП становила $3,3 \%$, приживання тканинного клаптя - 96,7\%.

Значення показників функціонального статусу за шкалою PSS-HN через 6 міс після хірургічного лікування: повноцінність дієти $-83,7 \pm 9,3$ бала, харчування на людях $80,8 \pm 14,2$ бала, зрозумілість мови $-87,5 \pm 12,7$ бала.

Пластичне заміщення субтотальних дефектів язика. Аналіз ускладнень після пересадки ПКП показав нижченаведені результати. Венозний тромбоз мікросудинного анастомозу розвинувся у $3(9,7 \%)$ хворих. Тромбектомія та накладання реанастомозу дозволили відновити венозний дренаж тканинного клаптя у 1 (3,2 \%) пацієнта. Повний некроз клаптя відмічений у $2(6,5 \%)$ хворих, часткових та крайових некрозів у пацієнтів цієї групи не спостерігали. У цих хворих проведені повторні реконструктивні втручання із застосуванням шкірном'язового клаптя великого грудного м'яза. Отже, частота розвитку некрозу ПКП становила 6,5\%, приживання тканинного клаптя - 93,5\%. Етапи реконструктивного лікування хворого С. представлено на рис. 1-4.
Значення показників функціонального статусу за шкалою PSS-HN через 6 міс після хірургічного лікування: повноцінність дієти $-61,0 \pm 9,4$ бала, харчування на людях $64,5 \pm 12,5$ бала, зрозумілість мови $-66,1 \pm 12,2$ бала.

Пластичне заміщення дефектів щоки. Аналіз ускладнень після пересадки ПКП показав такі результати: у 1 (7,1 \%) хворого розвинувся повний некроз клаптя, пов'язаний з венозним тромбозом мікросудинного анастомозу. У цього пацієнта виконано повторне реконструктивне втручання із застосуванням шкірно-фасціального клаптя надключичної артерії. Часткового та крайового некрозу тканинних клаптів у пацієнтів цієї групи не спостерігали. Отже, частота розвитку некрозу ПКП становила $7,1 \%$, приживання тканинного клаптя - 92,9\%. Етапи реконструктивного лікування хвороїД. представлено на рис. 5-10.

Значення показників функціонального статусу за шкалою PSS-HN через 6 міс після хірургічного лікування: повноцінність дієти $-85,7 \pm 13,4$ балів, харчування на людях $80,6 \pm 14,5$ балів, зрозумілість мови $-92,9 \pm 11,6$ балів.

Порівняння ефективності венозних систем ПКП. При пересадці ПКП у всіх 75 хворих накладено один венозний мікросудинний анастомоз. Із них у 71 пацієнта накладено один венозний мікросудинний анастомоз з глибокою або поверхневою венозною системою ПКП, у 4 - один венозний мікросудинний анастомоз з включенням глибокої та поверхневої венозної систем ПКП.

У $47(66,2 \%)$ із 71 хворого було накладено один венозний мікросудинний анастомоз з глибокою венозною системою ПКП, у $24(33,8 \%)$ із 71 хворого - 3 поверхневою венозною системою ПКП. Тромбоз мікросудинного анастомозу у групі пацієнтів, яким один венозний анастомоз накладали з глибокою венозною системою тканинного клаптя розвинувся у $3(6,4 \%)$ випадках, а у групі, у якій венозний анастомоз накладали з поверхневою венозною системою - у $2(8,3 \%)(\mathrm{p}>0,05)$.

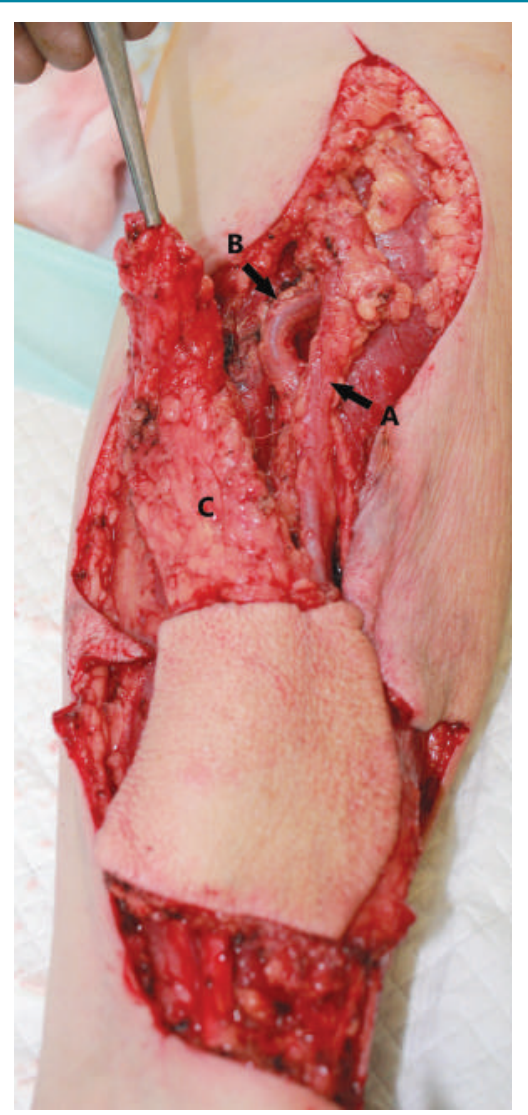

Рис. 1. Виділений променевий клапоть передпліччя. А - головна вена; В - променева артерія з комітантними венами; C - підшкірна жирова клітковина передпліччя, виділена та включена до складу тканинного клаптя 
У 4 хворих накладено один венозний мікросудинний анастомоз з включенням глибокої та поверхневої венозної систем ПКП за допомогою антекубітальної перфорантної вени. У всіх випадках анастомоз був накладений з головною веною (рис. 11-13). Венозної недостатності ПКП не спостерігали в жодному з випадків.

Дотепер ПКП залишається методом вибору для пластичного заміщення різних операційних дефектів голови та шиї у онкологічних хворих. У нашому дослідженні продемонстровано досить високі показники функціонального статусу
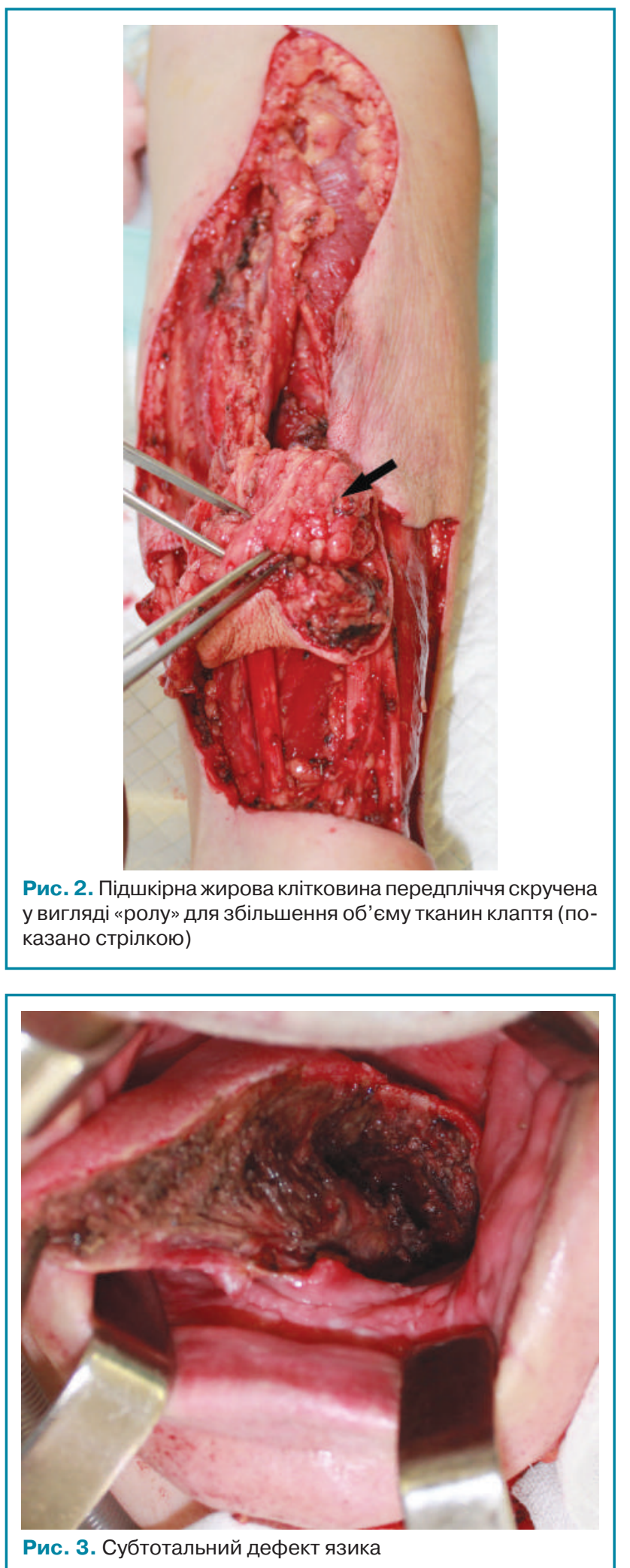

при застосуванні ПКП для реконструкції язика та щоки. Про подібні показники функціональної реабілітації повідомляється і за результатами інших досліджень $[8,16]$.

Частота втрати ПКП при пластичному усуненні дефектів голови та шиї коливається в межах 0-10\%. Основною причиною втрати тканинного клаптя є венозна недостатність. Дотепер відсутній консенсус щодо того, яка венозна система $\epsilon$ більш оптимальною для накладання анастомозу при пересадці ПКП [12]. У нещодавньому метааналізі, у якому порівнювали поверхневу та глибоку венозні системи ПКП при накладанні одного венозного мікросудинного анастомозу не визначено оптимального типу венозної системи [14]. У нашому дослідженні не встановлено достовірних відмінностей у частоті венозної недостатності ПКП при застосуванні глибокої та поверхневої венозної систем тканинного клаптя у разі накладання одного венозного анастомозу.

Відсутній консенсус і щодо дренування ПКП обома венозними системами з накладанням двох мікросудинних анастомозів та однією венозною системою з накладанням одного анастомозу. У дослідженні N. Futran та B. Stack не встановлено різниці у приживанні ПКП при застосуванні одного та двох венозних мікросудинних анастомозів. Крім того, автори стверджували, що додаткова ендотеліальна травма в ділянці

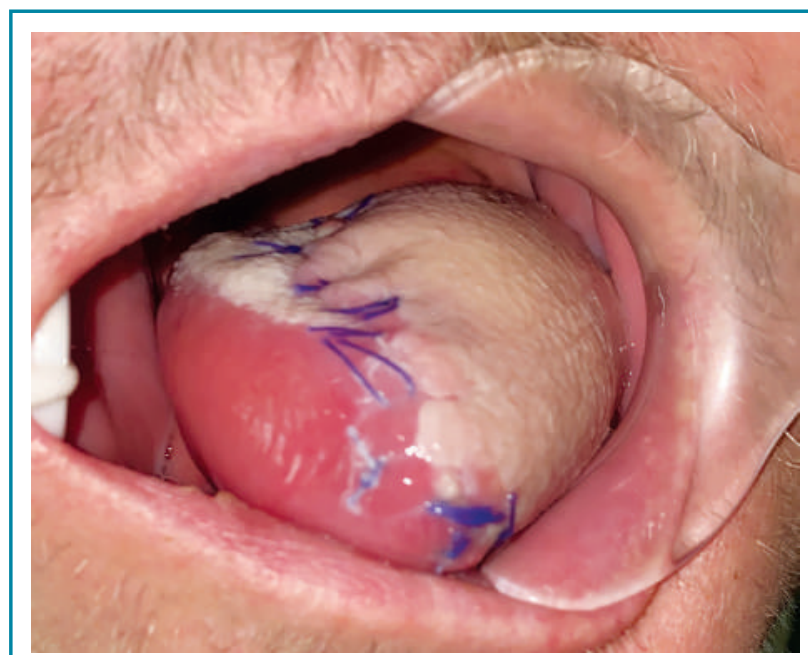

Рис. 4. Результат пластичного заміщення субтотального дефекту язика ПКП. Стан через 2 тиж після реконструктивного лікування

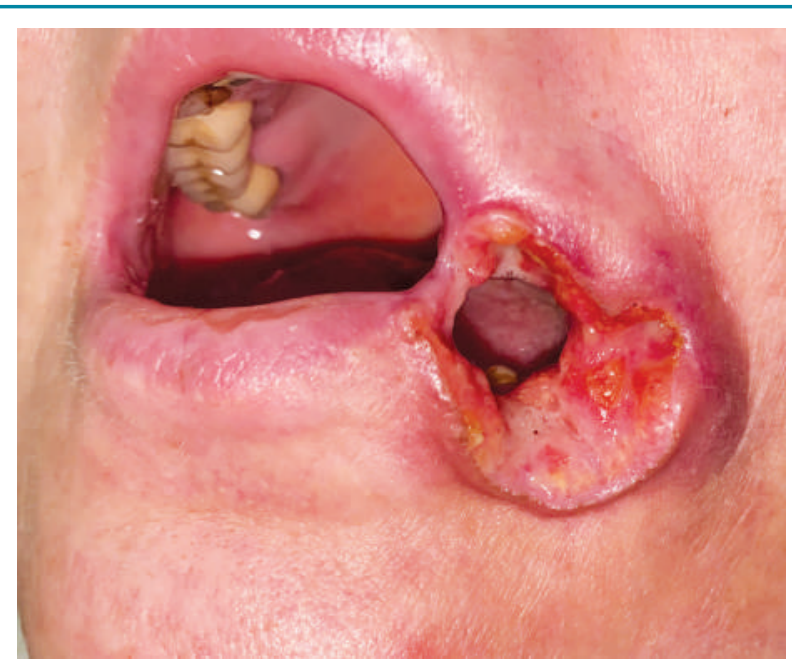

Рис. 5. Вигляд первинної пухлини слизової оболонки щоки (наскрізний дефект щоки). Метастатичне ураження лімфатичного вузла IB рівня (показано стрілкою) 


\section{Оригінальні статті / Original Articles}

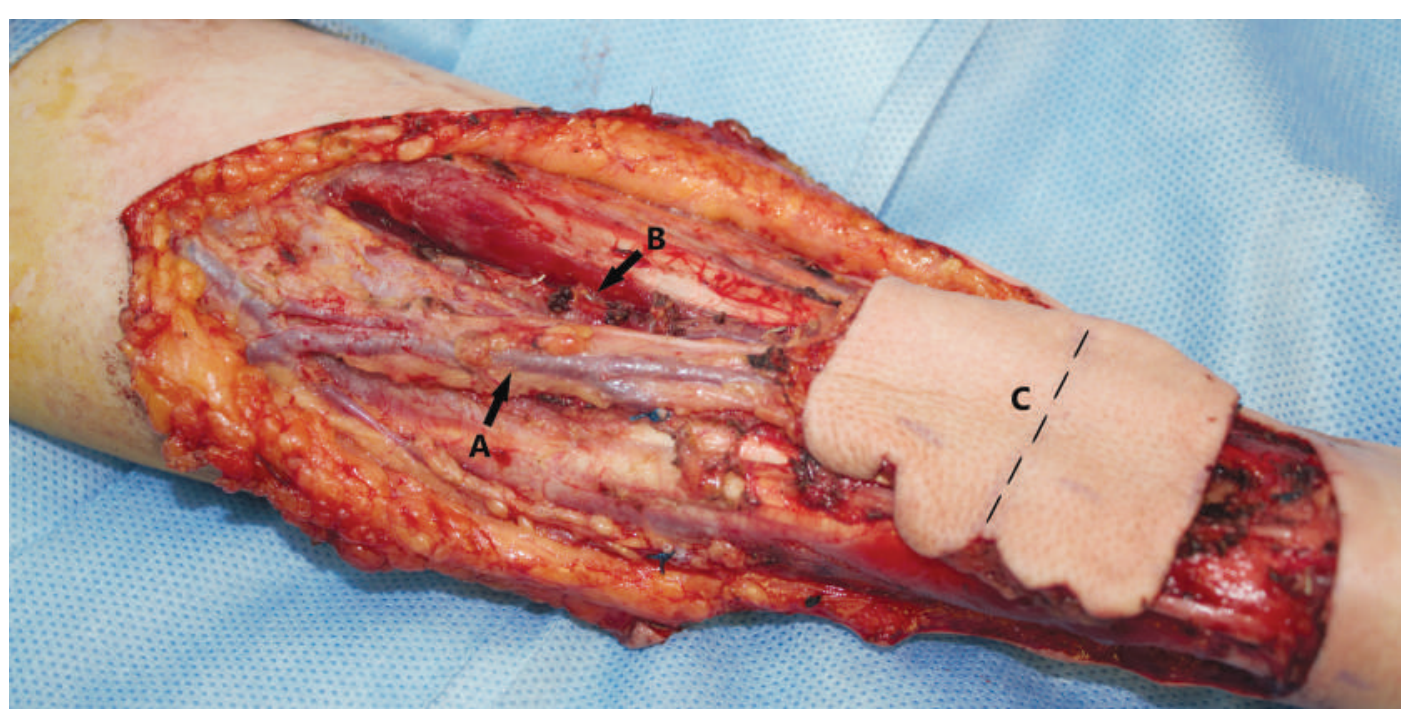

Рис. 6. Виділений променевий клапоть передпліччя: А - головна вена; В - променева артерія з комітантними венами; C - маркована ділянка згину та деепідермізації тканинного клаптя, який буде використаний для одночасного заміщення двох епітеліальних поверхонь - слизової оболонки щоки та шкіри щоки

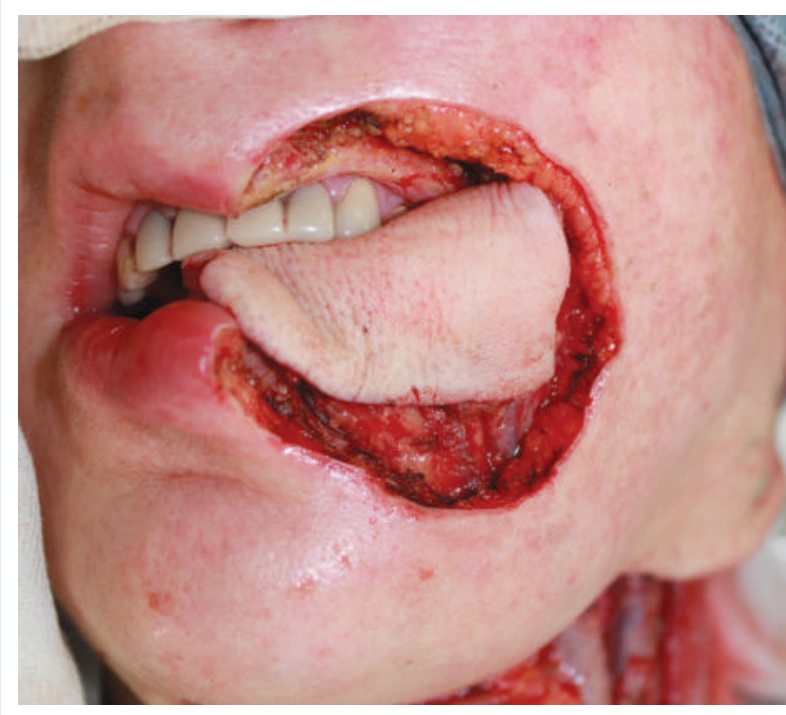

Рис. 7. ПКП укладений у ділянку дефекту щоки

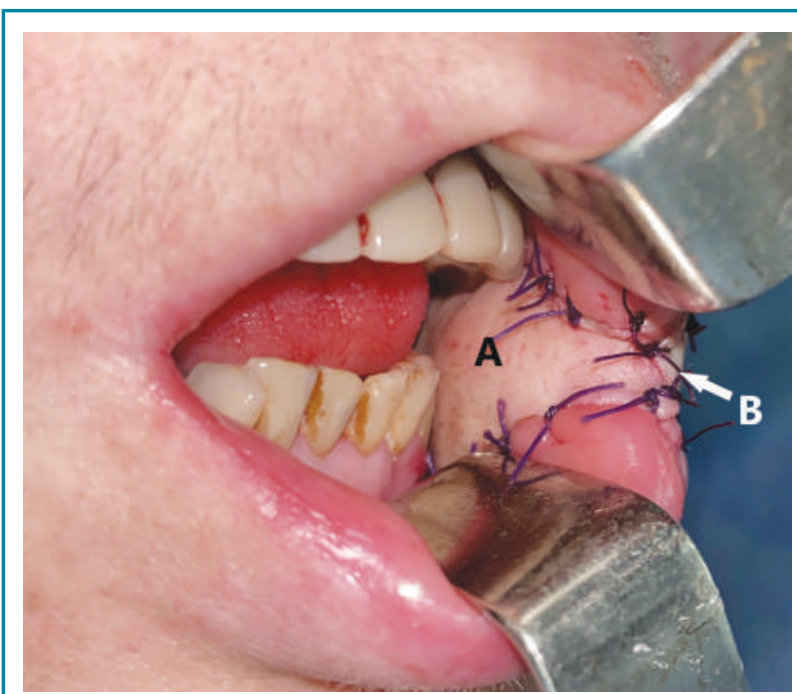

Рис. 9. Заміщений дефект слизової оболонки щоки (А), сформована комісура рота (В)

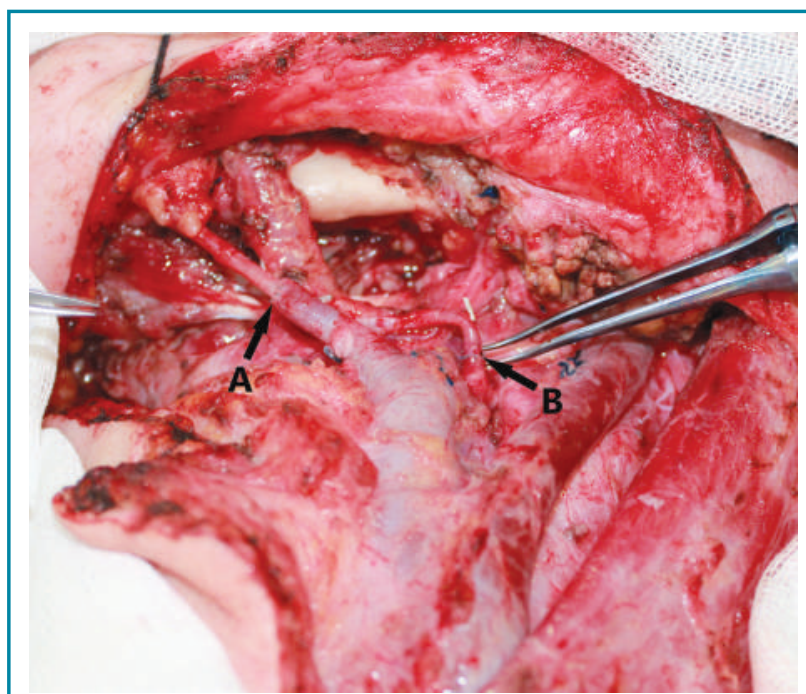

Рис. 8. Накладені венозний (А) та артеріальний (В) мікросудинні анастомози

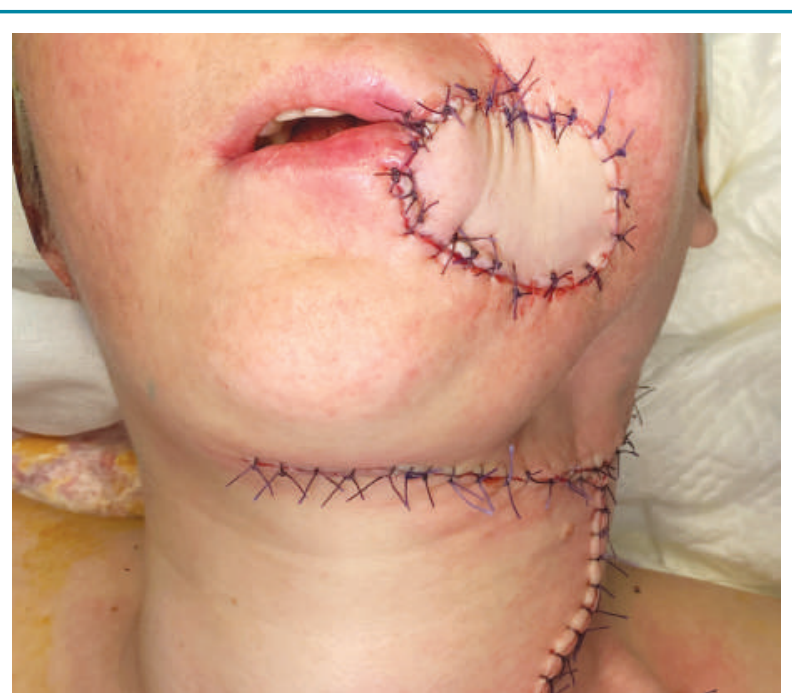

Рис. 10. Безпосередній результат пластичного заміщення наскрізного дефекту щоки ПКП. 


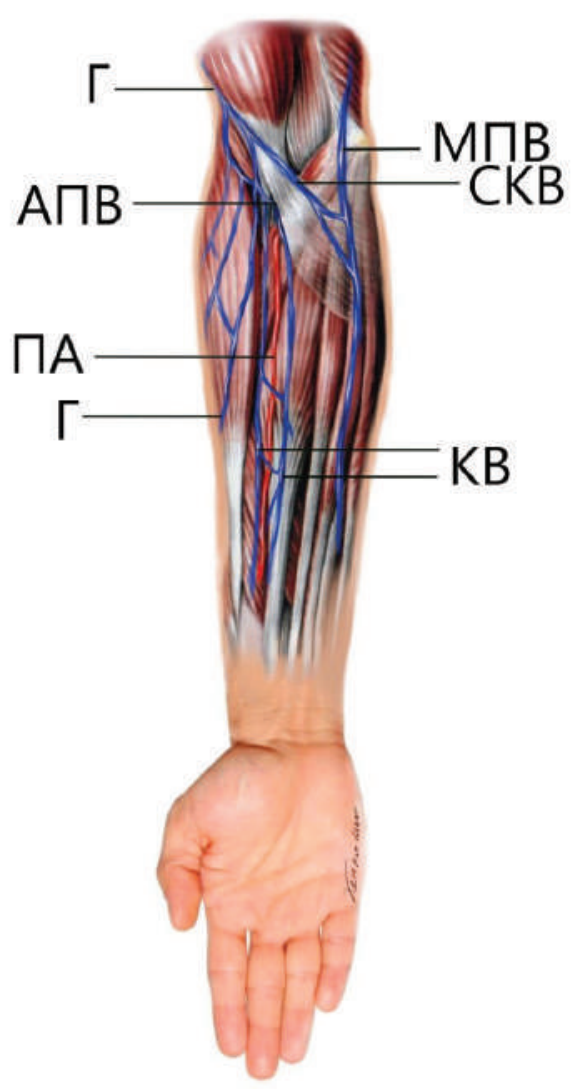

Рис. 11. Схематичне зображення поверхневої та глибокої венозних систем передпліччя: Г — головна вена; КВ - комітантні вени променевої артерії; ПА - променева артерія; АПВ - антекубітальна перфорантна вена; СКВ - серединна кубітальна вена; МПВ - медіальна підшкірна вена

другого венозного анастомозу у поєднанні з паралельним дренажним шляхом, що знижує тиск у обох венах, підвищує ризик утворення тромбу [17].

На противагу результатам вищезазначеного дослідження А. Ichinose та співавтори дішли висновку, що два венозних мікросудинних анастомози з поверхневою та глибокою венозними системами знижують ризик розвитку тромбозу. Автори припустили, що накладання двох анастомозів з обома венозними

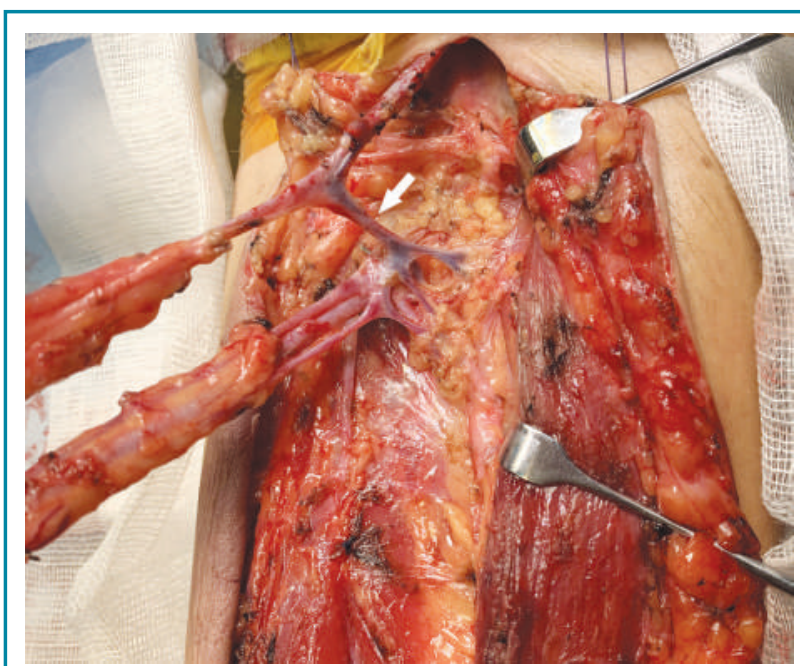

Рис. 12. Виділена антекубітальна перфорантна вена, яка з'єднує поверхневу та глибоку венозні системи ПКП (показано стрілкою) системами забезпечує надійний механізм, що зберігає частковий відтік крові, якщо в одній із вен утворюється тромб [18].

Упродовж останніх років спостерігається відновлення інтересу до методики забору ПКП з подвійним венозним дренажем за рахунок виділення антекубітальної перфорантної вени, яка з'єднує поверхневу та глибоку венозні системи та накладанням єдиного анастомозу з головною або серединно-кубітальною веною. У дослідженні С. Sader та співавторів проведено 158 пересадок ПКП з подвійним венозним дренажем. Антекубітальну перфорантну вену було візуалізовано та виділено у $98,1 \%$ хворих [19]. У іншому дослідженні антекубітальну перфорантну вену було візуалізовано та включено до складу судинної «ніжки» у 84,7\% пацієнтів. Автори повідомляють про приживання ПКП у 98,4\% хворих та приходять до висновку, що забір тканинного клаптя з подвійним венозним дренажем через єдиний анастомоз є успішною альтернативою іншим методикам використання обох венозних систем, описаним у попередніх публікаціях [12].

Слід зауважити, що деякі автори припускають, що довга судинна «ніжка», яка включає головну вену разом з комітантними венами, $€$ потенційним джерелом патології донорської ділянки, такої як лімфедема [20]. Однак М. Moreno та співавтори повідомили, що хронічна лімфедема не відмічалася у жодного із 61 хворих, яким використано ПКП з подвійним венозним дренажем через єдиний анастомоз [12].

У нашому дослідженні пересаджено 4 ПКП з подвійним венозним дренажем через єдиний мікросудинний анастомоз з головною веною. Венозної недостатності тканинного клаптя не спостерігали в жодному з випадків. На нашу думку, методика пересадки ПКП з подвійним венозним дренажем через єдиний мікросудинний анастомоз є перспективною, оскільки може знизити частоту післяопераційних ускладнень та покращити приживання ПКП.

\section{ВИСНОВКИ}

Використання ПКП є ефективною методикою пластичного заміщення операційних дефектів язика і щоки, що дозволяє досягнути високих показників приживання тканинного клаптя та функціональної реабілітації онкологічних хворих.

Не встановлено відмінностей у частоті венозного тромбозу при застосуванні ПКП з поверхневою та глибокою венозними системами.

Перспективним є дослідження ефективності методики пересадки ПКП з подвійним венозним дренажем через єдиний мікросудинний анастомоз.

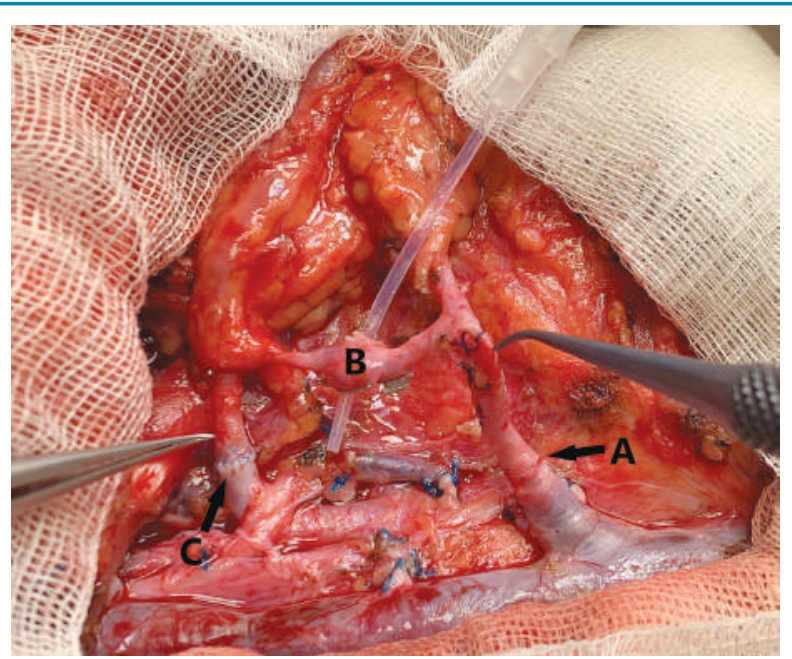

Рис. 13. Накладений венозний мікросудинний анастомоз з головною веною (А); антекубітальна перфорантна вена (В); артеріальний мікросудинний анастомоз (С) 


\section{СПИСОК ВИКОРИСТАНОÏ ЛІТЕРАТУРИ}

1. Yang, G-F, Chen, P-J, Gao, Y-Z, Liu, X-Y, Li, J, Jiang S-X, \& He, S-F. (1981). Forearm free skin flap transplantation: a report of 56 cases. National Medical Journal of China, 61, 139-141.

2. Grinsell, D, \& Herle, P. (2019). Composite pronator quadratus: radial forearm free flap in functional lip reconstruction. ANZ Journal of Surgery, 89(7-8), 940-944. doi: 10.1111/ans. 14980 .

3. Wang, C, Fu, G, Ji, F, Cheng, S, Liu, Z, \& Cao, M. (2020). Perioperative Risk Factors for Radial Forearm-Free Flap Complications. Journal of Craniofacial Surgery 31(2), 381-384. doi: 10.1097/SCS.0000000000006035.

4. Choi, J, Choi, HJ, Kang, KJ, \& Jung, SN. (2019). Three-Surface Reconstruction Using Single De-Epithelialized Radial Forearm Free Flap. Journal of Craniofacial Surgery, 30(4), e343-e344. doi: 10.1097/SCS.0000000000005329.

5. Pangrazi, PP, De Francesco, F, Di Rienzo, A, \& Riccio, M. (2019). Adipofasc ial Radial Forearm Free Flap for Anterior Skull Base Reconstruction in Complicated Forebrain Oncological Surgery. Journal of Craniofacial Surgery, 30(6), 1724-1729. doi: $10.1097 /$ SCS.0000000000005559.

6. Sokoya, M, Vincent, A, Cohn, JE, Kadakia, S, Kohlert, S, \& Ducic, Y. (2019) Comparison of radial forearm free flap and gastric pull-up in pharyngo-oesophagea reconstruction. Clinical Otolaryngology, 44(3), 405-407. doi: 10.1111/coa.13279.

7. Dziegielewski, PT, Rieger, J, Shama, MA, O'Connell, DA, Harris, JR, \& Seikaly, H. (2019). Beavertail modification of the radial forearm free flap in total oral glossectomy reconstruction: Technique and functional outcomes. Oral Oncology, 96, 71-76. doi: 10.1016/j.oraloncology.2019.07.004

8. Zhang, PP, Meng, L, Shen, J, Liu, H, Zhang, J, Xiang, X, \& Yan, YB. (2018) Free radial forearm flap and anterolateral thigh flap for reconstruction of hemiglossectomy defects: A comparison of quality of life. Journal of Cranio-Maxillofacial Surgery, 46(12), 2157-2163. doi: 10.1016/j.jcms.2018.10.006.

9. Gonzalez-Castro, J, Petrisor, D, Ballard, D, \& Wax, MK. (2016). The doublebarreled radial forearm osteocutaneous free flap. Laryngoscope, 126(2), 340-344. doi: 10.1002/lary.25388.

10. Potet, P, De Bonnecaze, G, Chabrillac, E, Dupret-Bories, A, Vergez, S, \& Chaput B. (2020). Closure of radial forearm free flap donor site: A comparative study between keystone flap and skin graft. Head Neck, 42(2), 217-223. doi: 10.1002/hed.25977.

11. Harris, BN, \& Bewley, AF. (2016). Minimizing free flap donor-site morbidity. Current Opinion in Otolaryngology \& Head \& Neck Surgery, 24(5), 447-52. doi: 10.1097/MOO.0000000000000286

12. Moreno, MA, Small, LT, Gardner, JR, Kim, AH, Vural, E, \& Sunde, J. (2021). Outcomes of Single Anastomoses for Superficial and Deep-System Venous Drainage of Radial Forearm Free Flaps. OTO Open, 5(2):2473974X211006927. doi: 10.1177/2473974X211006927.

13. Cha, YH, Nam, W, Cha, I-H, \& Kim, HJ. (2017). Revisiting radial forearm free flap for successful venous drainage. Maxillofacial Plastic and Reconstructive Surgery, 39(1), 14. doi: 10.1186/s40902-017-0110-8

14. Xie, $Y$, Feng, $T$, Ou, Y, Lin, $Y$, Gong, $W$, \& Wang, Y. (2021). Superficial versus deep system single venous anastomosis in the radial forearm free flap: a metaanalysis. International Journal of Oral and Maxillofacial Surgery, 50(7), 873-878. doi: 10.1016/jijom.2020.11.007.

15. Golash, A, Bera, S, Bhaviya, BS, Kanoi,AV, Pai, AA, \& Golash, A. (2019). Clinical utility of the communicating vein in free radial artery forearm flaps: best of both worlds. Journal of Plastic, Reconstructive \& Aesthetic Surgery, 72(7), 1219-1243. doi: 10.1016/j.bjps.2019.03.007.

16. Qi-Gen, Fang, Zhen-Ning, Li, Xu, Zhang, Fa-Yu, Liu, Zhong-Fei, Xu, \& Chang-Fu, Sun. (2013). Clinical reliability of radial forearm free flap in repair of buccal defects. World Journal of Surgical Oncology, 11(1), 26. doi: 10.1186/1477-7819-11-26.

17. Futran, ND, \& Stack, BC. (1996). Single versus dual venous drainage of the radial forearm free flap. American Journal of Otolaryngology and Head and Neck Surgery, 17(2), 112-117. doi: 10.1016/s0196-0709(96)90006-x.

18. Ichinose, A, Tahara, S, Yokoo, S, Omori, M, Miyamura, S, Tsuji, Y, \& Saito, M. (2003). Fail-Safe Drainage Procedure in Free Radial Forearm Flap Transfer. Journal of Reconstructive Microsurgery, 19(6), 371-376. doi:10.1055/s-2003-42631.

19. Sader, C, Hart, RD, Trites, JRB, Rigby, MH, Phillips, T, \& Taylor, SM. (2010). The communicating vein in the radial forearm free flap. Plastic and Reconstructive Surgery, 126(2), 105e-107e. doi: 10.1097/prs.0b013e3181de25e4

20. Golash, A, Bera, S, Bhaviya, BS, Kanoi, AV, Pai, AA, \& Golash, A. (2019). Clinical utility of the communicating vein in free radial artery forearm flaps: best of both worlds. Journal of Plastic, Reconstructive \& Aesthetic Surgery, 72(7), 1219-1243. doi: 10.1016/j.bjps.2019.03.007.

Лучевой лоскут предплечья в реконструктивной хирургии головы и шеи. Опыт применения и выбор венозной системы тканевого лоскута

\section{О.В. Кравец, В.В. Черниенко, О.В.Буртын, И.И.Смоланка (мл.)}

Национальный институт рака, Киев

Резюме. Введение. Методики забора лучевого лоскута предплечья (ЛЛП) постоянно совершенствуются и направлены на снижение частоты послеоперационных осложнений, улучшение приживания тканевого лоскута и функциональных результатов реконструкции. Цель. Изучить функциональные результаты применения ЛЛП для замещения дефектов языка и щеки и сравнить эффективность венозных систем тканевого лоскута. Материалы и методы. Проведен ретроспективный анализ результатов реконструктивно-восстановительного лечения 75 больных с местно-распространенным плоскоклеточным раком языка и слизистой оболочки щеки, у которых для пластического замещения операционных дефектов использован ЛЛП в Национальном институте рака в период
2009-2020 гг. Результаты. Показатели функционального статуса по Шкале функционирования для больных раком головы и шеи (Performance Status Scale for Head and Neck Cancer Patients - PSS-HN) при замещении половинных дефектов языка, субтотальных дефектов языка и дефектов щеки: полноценность диеты $-83,7 \pm 9,3 ; 61,0 \pm 9,4 ; 85,7 \pm 13,4$ балла соответственно; питание на людях $-(80,8 \pm 14,2) ;(64,5 \pm 12,5) ;(80,6 \pm 14,5)$ баллов соответственно; понятность речи $-87,5 \pm 12,7 ; 66,1 \pm 12,2$; $92,9 \pm 11,6$ балла соответственно. В группе больных, которым один венозный анастомоз накладывали с глубокой венозной системой ЛЛП, тромбоз микрососудистого анастомоза развился в $3(6,4 \%)$ случаях, а в группе, в которой венозный анастомоз накладывали с поверхностной венозной системой - в $2(8,3 \%)$ (р $>0,05)$. Выводы. Применение ЛЛП является эффективной методикой пластического замещения операционных дефектов языка и щеки, что позволяет достичь высоких показателей приживания тканевого лоскута и функциональной реабилитации онкологических больных. Не установлены различия в частоте венозного тромбоза при применении ЛЛП с поверхностной и глубокой венозной системами.

Ключевые слова: лучевой лоскут предплечья; дефект; функциональный статус; венозная система.

Radial forearm flap in head and neck reconstructive surgery. Application experience and selection of the venous system of the tissue flap

\section{O.V. Kravets, V.V. Cherniienko, O.V. Burtyn, Smolanka I.I. (Jr)}

National Cancer Institute, Kyiv

Abstract. Introduction. Methods of removal of the radial forearm flap (RFF) are constantly being developed. These methods are aimed at reducing the frequency of postoperative complications, improving the survival of the tissue flap and the functional outcomes of reconstruction. Aim. To study the functional outcomes of the use of RFF for repairing defects of the tongue and cheeks, as well as compare the effectiveness of the venous systems of the tissue flap. Materials and methods. There was conducted a retrospective study of the outcomes of reconstructive treatment of 75 patients with locally advanced squamous cell carcinoma of the tongue and buccal mucosa who had plastic repair of surgical defects with the use of RFF at the National Cancer Institute over the period 2009-2020. Results. Functional status measures on the Performance Status Scale for Head and Neck Cancer Patients in the repair of half-tongue defects, subtotal tongue defects and cheek defects: normalcy of diet $-83.7 \pm 9.3$; $61.0 \pm 9.4 ; 85.7 \pm 13.4$ points, respectively; eating in the presence of other people $-80.8 \pm 14.2 ; 64.5 \pm 12.5 ; 80.6 \pm 14.5$ points, respectively; speech intelligibility $-87.5 \pm 12.7 ; 66.1 \pm 12.2 ; 92.9 \pm 11.6$ points, respectively. In the group of patients where one venous anastomosis was imposed with a deep venous system of RFF, thrombosis of the microvascular anastomosis developed in $3(6.4 \%)$ cases, and in the group where a venous anastomosis was imposed with a superficial venous system it occurred in $2(8.3 \%)(p>0.05)$. Conclusions. The use of RFF is an effective method of plastic repair of surgical defects of the tongue and cheeks, which allows achieving high survival rates of the tissue flap and functional rehabilitation of cancer patients. There has not been revealed any differences in the frequency of venous thrombosis when using RFF with superficial and deep venous systems. system.

Key words: radial forearm flap; defect; functional status; venous

Aдреса:
Черніснко Віктор
Озо22 Киів, вул. Ломоносова, 33/43
Hаціональний інститут раку
E-mail: viktor.cherniienko@gmail.com
Correspondence:
Cherniienko Viktor
National Cancer Institute
National Cancer Institute E-mail: viktor.cherniienko@gmail.com

